\title{
GENDER IN AUTOMOBILE INSURANCE UNDERWRITING: SOME INSUREDS ARE MORE EQUAL THAN OTHERS
}

\author{
KENT WEST ${ }^{*}$
}

This article examines the use of gender as a variable by the insurance industry to determine insurance premiums. This article explores the tension between society's abhorrence of sexual discrimination on one hand, and the insurance industry's need for a cost-effective method of classifying risk on the other. Following an analysis of how gender-based classification has been treated by Canadian and international courts, this article recommends that gender-based classification in Canada be eventually phased out.
Cet article examine l'usage du genre comme variable dans le secteur de l'assurance pour déterminer les primes d'assurance. L'article explore la tension qui existe d'une part entre l'aversion de la discrimination sexuelle de la société et d'autre part le besoin du secteur d'avoir une méthode économique de classifier le risque. À la suite d'une analyse de la manière dont une classification basée sur le sexe a été traitée devant les tribunaux canadiens et internationaux, cet article recommande qu'une telle classification soit un jour retirée progressivement au Canada.

\section{TABLE OF CONTENTS}

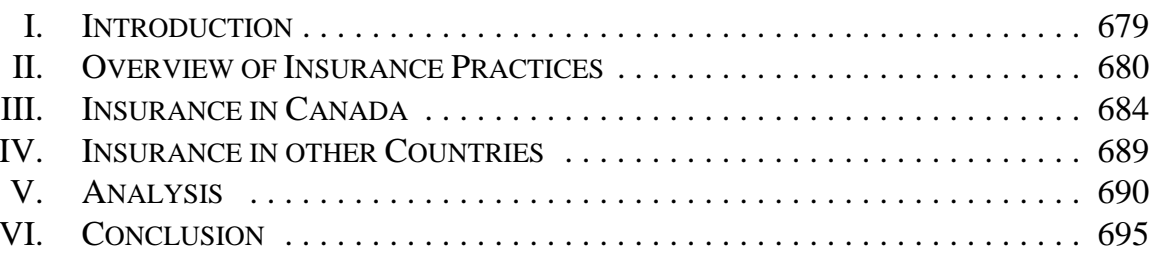

\section{INTRODUCTION}

Contemporary Western society enjoys a great deal of economic strength and stability due in no small measure to the ever-present (and frequently misunderstood) institution of insurance. Through the sharing of risk, insurance allows for the growth and development of commerce and, on a more fundamental level, provides some financial peace of mind in a world of constant uncertainty. At the same time, the manner in which insurance operates reflects many of the values held by the legal system and society as a whole. Discussion around insurance often involves topics such as individual freedom, equality, and the proper role of government. Issues within the insurance industry are not always purely economic and can also be highly political or even philosophical in nature.

One example, which is the subject of this article, concerns the type of variables that the insurance industry uses to classify individuals who apply for coverage. The economic stability of many insurance programs depends on the ability of insurers to differentiate risks according to a predetermined set of criteria. For instance, auto insurers have historically used factors such as a driver's accident history to determine insurance premiums. More controversial factors like age, gender, and even marital status are sometimes also considered 
in setting premiums; however, some criteria, such as race or religion, are almost never used. ${ }^{1}$ This article will explore why certain factors are permitted in the assessment of auto insurance premiums while others are not, addressing one such factor in particular: gender.

Gender occupies a unique position among possible risk factors. Insurers in many jurisdictions still use gender as a rating variable, despite the fact that most human rights legislation specifically prohibits gender as a basis for discrimination in the provision of commercial services. Disagreement over this practice has caused some jurisdictions to put an end to the use of gender as a rating variable. ${ }^{2}$ There are compelling commercial and economic arguments that support the use of gender as a rating variable. Recently, there has been no significant discussion in legal literature or by Canadian courts as to whether these arguments justify the use of gender as a risk factor for setting insurance premiums under current Canadian law. It is odd that there has been such an absence of discussion in this area, especially given the growing intolerance in Western society toward gender discrimination of almost any form. Accordingly, focusing on the example of automobile insurance, this article will address the following issue: is it legally justifiable for Canadian insurers to use gender as a rating variable in determining risk and assessing premiums? Auto insurance has been selected as the subject of analysis because it is the most common form of insurance purchased by Canadians. ${ }^{3}$ Changes to the rating system in this industry would have a significant and widespread impact on the public.

This article begins with an overview of common insurance practices, including risk differentiation and how it relates to the concept of equality. The overview is intended to highlight the conflict between the economic principles of insurance and the application of modern human rights legislation. Part II explores the use of gender as a rating variable in Canadian jurisdictions in the context of Canadian equality laws. Examples from selected provinces demonstrate the disparity between the various provincial insurance industries, both public and private, and how they approach the issue of gender rating in insurance. Part III discusses examples from other countries and emerging trends in global auto insurance practices. Particular focus is given to the approaches taken in some American states and recent case law from the European Court of Justice (ECJ). Drawing on the preceding sections, Part IV evaluates the merits of using gender as a rating variable in automobile insurance, given the importance of equality in Canadian law.

\section{OVERVIEW OF INSURANCE Practices}

The mechanics of insurance can be both beautiful in their simplicity and overwhelming in their apparent complexity. The purpose of insurance is elegantly summarized in the following quote by a nineteenth century American lawyer:

$1 \quad$ Jill Gaulding, “Race, Sex, and Genetic Discrimination in Insurance: What’s Fair?” (1995) 80:6 Cornell L Rev 1646 at 1658-1664; Robert H Jerry, II \& Kyle B Mansfield, “Justifying Unisex Insurance: Another Perspective” (1985) 34:2 Am U L Rev 329 at 359-60; Wanda A Wiegers, "The Use of Age, Sex, and Marital Status as Rating Variables in Automobile Insurance” (1989) 39:2 UTLJ 149 at 150, 158.

See notes 32-35 below.

Insurance Bureau of Canada (IBC), Facts of the General Insurance Industry in Canada, 34 ed (Toronto: IBC, 2009) at 8, online: IBC < http://www.ibc.ca/en/need_more_info/documents/facts\%book\%202009 _eng.pdf $>$ [IBC, Facts]. 
Insurance, therefore, takes from all a contribution; from those who will not need its aid, as well as from those who will; for it is as certain that some will not, as that some will. But as it is uncertain who will, and who will not, it demands this tribute from all to the uncertainty of fate. And it is precisely the moneys thus given away by some, and these only, which supply the fund out of which the misfortune of those whose bad luck it is that their moneys have not been thrown away, are repaired. The afflicted finds his money spent to some purpose; and only the fortunate part with it for nothing. From this point of view the whole beauty of the system of insurance is seen. ${ }^{4}$

Essentially, insurance creates a pool of money which is funded through the premiums paid by all insureds. When an insured experiences a loss, he or she is compensated from this fund. Since it is unclear whom among the many insureds will experience a loss through the "uncertainty of fate," this risk of loss is spread evenly across all insureds rather than being borne entirely by a few unlucky individuals.

One problem, however, is that not every insured brings the same amount of risk to the pool. Some are more or less likely to experience a loss than others for various reasons. This issue is central to the economics of insurance, as it can result in two major problems: "moral hazard" and "adverse selection." 5 Both of these phenomena can prevent the proper functioning of insurance and must be dealt with by insurers in some fashion in order to maintain a viable industry.

Moral hazard describes the tendency of insureds to behave differently when no longer exposed to risk. ${ }^{6}$ After purchasing insurance, the insured ceases to bear the same degree of risk because, if a loss occurs, it will be paid by the insurance company. The insured will, therefore, have a lowered incentive to avoid a loss. Such a reduced incentive can, on a large scale, cause an increase in overall loss rates and can be damaging to the effectiveness of the insurance system. Taken to its extreme, total loss payouts could exceed the total premium collected.

Adverse selection refers to the tendency for low-risk individuals to avoid insurance and for high-risk individuals to seek it. ${ }^{7}$ If every insured is charged the same rate based on the overall average level of risk, low-risk individuals will feel that they are overpaying and will be more likely to drop out of the risk pool. High-risk individuals, on the other hand, will feel that they are getting a bargain and will be more likely to join the pool. This will result in a gradual increase in the average risk of the pool as the number of high-risk applicants increases and the number of low-risk applicants decreases. Ultimately, this will cause a corresponding increase in loss rates over time and a destabilization of the risk pool.

DR Jaques, “Society on the Basis of Mutual Life Insurance” (1847) 16 Hunt’s Merchants’ Magazine \& Commercial Review 152 at 158, cited in Tom Baker, "Containing The Promise of Insurance: Adverse Selection and Risk Classification” (2002-2003) 9:2 Conn Ins LJ 371 at 371-72. 
One method of addressing these problems is through risk differentiation and classification. ${ }^{8}$ This refers to "the process of sorting insurance applicants into categories believed to correspond to differences in expected risk." ${ }^{9}$ Simply put, high-risk insureds and low-risk insureds are grouped with others of the same perceived risk level and charged premiums accordingly. Moral hazard can be addressed in this way because those who present a higher risk have an incentive to take preventative measures to reduce their perceived risk level. If they are able to do so, they may gain entry to a lower-risk pool and may be charged a lower premium. ${ }^{10}$ Conversely, those who engage in high-risk behavior are punished by being bumped into high-risk pools with higher premiums. For instance, a driver who receives a speeding ticket will have his premium increased, creating a financial incentive to drive more slowly, lowering his potential for loss and the premiums he must pay.

In the case of adverse selection, the only solution is risk differentiation. ${ }^{11}$ Low-risk individuals are grouped together and charged a lower premium, and high-risk individuals are grouped together and pay a higher premium. Through this process, low-risk insureds are not overcharged and will, therefore, remain in the risk pool. High-risk insureds are not undercharged and will not be enticed to join risk pools in disproportionate numbers.

Given the importance of risk differentiation, the next issue is how it is to be accomplished. Which factors may be used to determine whether an applicant for insurance is a relatively low-risk or a relatively high-risk individual? In auto insurance, factors such as the number of traffic convictions typically do not raise a great deal of controversy. However, factors such as race or religion are almost universally considered to be factors which cannot be used to classify risk, regardless of their statistical validity. ${ }^{12}$ Western society views racial or religious discrimination of almost any variety to be intolerable. Gender discrimination is generally treated with similar disapproval; however, insurers in many instances still use gender to determine auto premiums. Here we see that the idea of comprehensive risk differentiation conflicts with the idea of social equality.

A strong, viable insurance industry requires risk differentiation to some extent, but the use of certain factors may contradict our understanding of equality and fairness. From an actuarial perspective, risk differentiation is best accomplished when insurers are allowed to acquire as much information as possible and create risk pools which are defined as clearly and as narrowly as possible. ${ }^{13}$ However, there are constraints which limit the use of some factors. Cost presents a major dilemma in the collection of actuarial data. ${ }^{14}$ For example, it may be helpful to subject every motorist to an annual driving test to determine his or her capabilities on the road, but this would be prohibitively expensive and impossible to implement on a large scale. Social policy considerations are another limitation. As mentioned

Baker, ibid at 376; Faure, ibid at 86-89; Hato Schmeiser, Tina Störmer \& Joël Wagner, "Unisex Insurance Pricing: Consumers’ Perception and Market Implications” in Hato Schmeiser, ed, Working Papers on Risk Management and Insurance No 112 (St Gallen: Institute of Insurance Economics, University of St Gallen, 2012) at 4-5.

Baker, ibid at 376.

Faure, supra note 5 at 86.

Ibid at 87; Gerber, supra note 5 at 1207.

Gaulding, supra note 1 at 1658-64; Jerry \& Mansfield, supra note 1 at 359-60; Wiegers, supra note 1 at $150,158$.

Faure, supra note 5 at 87.

Ibid at 86; Wiegers, supra note 1 at 158-59. 
earlier, Western society has decided that race should not be used as a basis of distinguishing between individuals, even if it could be shown statistically that there is a relationship between a person's race and his or her risk as an insured. ${ }^{15}$

Gender occupies a somewhat unique place in this discussion. In most areas of society, gender cannot be used as a means of discrimination. An individual's wages cannot be raised or lowered, nor can someone be denied access to publicly available services based exclusively on gender. However, in some jurisdictions, gender is still used to determine the price of automobile insurance for an individual. There are several reasons commonly put forward in support of this practice. Most importantly, there is a statistically significant relationship between a person's gender and his or her risk of loss, particularly among young drivers. ${ }^{16}$ Young male drivers are much more likely to be involved in auto accidents and tend to cause much more damage than their female counterparts. ${ }^{17}$

Another crucial reason is that gender is an inexpensive way of differentiating between insureds. ${ }^{18}$ Although gender is not causally related to accident rates - in other words, being male or female does not cause car accidents - it is strongly correlated to other factors which are causally related to risk of loss. ${ }^{19}$ For example, young males may tend to drive more often than young females, thereby increasing their exposure to loss merely through higher overall mileage. ${ }^{20}$ Monitoring a causal factor like annual mileage is much more expensive than merely noting the applicant's gender and rating accordingly. ${ }^{21}$

Although the use of gender may be justified on an actuarial basis, the intention of this article is to determine whether this practice can be justified under Canadian law. Some jurisdictions in Canada have concluded that it is not justifiable, yet others continue to use gender as a way to assess risk. The next part of this article will provide an overview of insurance practices in some Canadian jurisdictions and describe examples in which certain provinces have moved away from this practice and adopted "unisex” rating systems.

15 See supra note 1 and the corresponding text.

16 Mark Milke, "Myths and Facts about Automobile Insurance in Canada” (27 December 2006), online: IBC < http://www.ibc.ca/en/media_centre/documents/2006releaseattachments/report_mythsfact_nrdec 27-06.pdf> at 42; US Department of Transportation, National Highway Traffic Safety Administration, National Motor Vehicle Crash Causation Survey: Report to Congress (Springfield, VA: National Technical Information Service, 2008), online: NHTSA <http://www-nrd.nhtsa.dot.gov/Pubs/811059. PDF>; Insurance Institute for Highway Safety, Highway Loss Data Institute, "Fatality Facts 2010: Gender,” online: Insurance Institute for Highway Safety, Highway Loss Data Institute <http://www. iihs.org/research/fatality.aspx?topicName=Gender >; Oxera, "The Impact of a Ban on The Use of Gender in Insurance” (7 December 2011), online: Oxera <http://www.oxera.com/oxera/media/oxera/down loads/reports/Oxera-report-on-gender-in-insurance.pdf?ext=.pdf $>$ at 29-30; Schmeiser, Störmer \& Wagner, supra note 8 at 11.

Ibid.

Wiegers, supra note 1 at 182.

Ibid at 152-53; Stephen R Ryan, “The Elimination of Gender Discrimination in Insurance Pricing: Does Automobile Insurance Rate Without Sex?,” (1986) 61:4 Notre Dame L Rev 748 at 763; Yves Thiery \& Caroline Van Schoubroeck, "Fairness and Equality in Insurance Classification” (2006) 31 The Geneva Papers 190 at 199.

Ibid.

Wiegers, supra note 1 at 182. 


\section{INSURANCE IN CANADA}

Insurance in Canada is provincially regulated and the structure of the industry in each province varies greatly. Some provinces, such as Alberta and Ontario, have private automobile insurance industries which allow for individual companies to operate independently, subject to a provincial regulatory authority. ${ }^{22}$ Other provinces, such as British Columbia, Saskatchewan, and Manitoba, have entirely public auto insurance industries in which the provincial government or a Crown corporation operate as the provider of at least the basic minimum coverage required. ${ }^{23}$ For the purposes of this article, the discussion will be restricted to common law jurisdictions within Canada.

A key factor in the relationship between the insurance industry and human rights law is the public versus private distinction. The Canadian Charter of Rights and Freedoms ${ }^{24}$ applies only to Parliament and the legislature of each province and to the federal and provincial governments. In other words, it does not apply to private transactions where the government is not involved. This is particularly relevant to the present discussion because the applicability of the Charter will depend on whether there is an element of government involvement in the provision of automobile insurance polices. For public insurance companies, such as the Insurance Corporation of British Columbia (ICBC) or Saskatchewan General Insurance (SGI), the applicability of the Charter is obvious. However, it may also be relevant in some instances where insurance is privately provided. For example, in Alberta, the content of the standard automobile policy must be approved by the province's Superintendent of Insurance. ${ }^{25}$ The Alberta regulations do not prohibit the use of gender in auto insurance rating and insurers in that province continue to use it under this permissive regime. The legislation does not mandate the use of gender, so the Charter would likely not be directly applicable. However, Charter principles are still relevant in that they inform the judicial understanding of discrimination, both as a legal concept and in terms of its application under provincial human rights legislation. This will be discussed further in Part IV.

Regarding equality issues, section 15 of the Charter states:

(1) Every individual is equal before and under the law and has the right to the equal protection and equal benefit of the law without discrimination and, in particular, without discrimination based on race, national or ethnic origin, colour, religion, sex, age or mental or physical disability.

(2) Subsection (1) does not preclude any law, program or activity that has as its object the amelioration of conditions of disadvantaged individuals or groups including those that are disadvantaged because of race, national or ethnic origin, colour, religion, sex, age or mental or physical disability.

IBC, “Car Insurance Where You Live,” online: IBC < http://www.ibc.ca/en/car_insurance_where_you_ live.asp> [IBC, “Car Insurance”].

Ibid.

Part I of the Constitution Act, 1982, being Schedule B to the Canada Act 1982 (UK), 1982, c 11, s 32 [Charter].

Insurance Act, RSA 2000, c I-3, s 551. 
The Supreme Court of Canada has provided some further guidance regarding the meaning of discrimination under the Charter. In the case of Andrews v. Law Society (British Columbia), Justice McIntrye explained discrimination as follows:

[I]n assessing whether a complainant's rights have been infringed under s. 15(1), it is not enough to focus only on the alleged ground of discrimination and decide whether or not it is an enumerated or analogous ground. The effect of the impugned distinction or classification on the complainant must be considered. Once it is accepted that not all distinctions and differentiations created by law are discriminatory, then a role must be assigned to s. 15(1) which goes beyond the mere recognition of a legal distinction. A complainant under s. 15(1) must show not only that he or she is not receiving equal treatment before and under the law or that the law has a differential impact on him or her in the protection or benefit accorded by law but, in addition, must show that the legislative impact of the law is discriminatory. ${ }^{26}$

Justice McIntyre's statement shows that not all differentiations are deemed discriminatory. There must be more than a mere distinction. This is especially relevant to the issue of insurance rating. The issue is essentially whether the practice of using gender as a rating factor is automatically discriminatory under the Charter, or merely the use of a legitimate distinction.

In R. v. Kapp, the Supreme Court of Canada set out the test for determining whether or not a transaction is to be considered discriminatory:

(1) Does the law create a distinction based on an enumerated or analogous ground?

(2) Does the distinction create a disadvantage by perpetuating prejudice or stereotyping? ${ }^{27}$

Applied to insurance contracts, any use of gender as a rating variable will clearly meet the first part of the test, as gender is expressly listed under section 15 of the Charter. The main issue is whether risk classification schemes actually have the effect of perpetuating prejudice or stereotyping.

As discussed above, public insurers are governed not only by provincial human rights legislation, but also by the Charter and would, therefore, be subject to the Kapp test. As a practical matter, however, this is a moot point because public automobile insurers in Canada do not currently use gender as a rating variable. British Columbia removed gender as a rating variable in 1979 with the introduction of the Automobile Insurance Non-Discrimination Act. ${ }^{28}$ The ICBC, established in 1973, acts as the sole provider of the basic compulsory auto insurance, ${ }^{29}$ and the ICBC continues to provide auto insurance rates without using gender as a variable. ${ }^{30}$ Similar to British Columbia, Saskatchewan and Manitoba both have provincially operated auto insurance systems. SGI is a Crown corporation, which has been the sole provider of auto coverage in the province since $1945 .{ }^{31}$ Since it was first created, SGI has

[1989] 1 SCR 143 at 182 [emphasis added].

2008 SCC 41, [2008] 2 SCR 483 at para 17 [Kapp].

SBC 1979, c 3, 17-18 [Auto Non-Discrimination Act].

ICBC, Service Plan 2012-2014 (Vancouver: ICBC, 2012) at 4, online: Government of British Columbia <http://www.bcbudget.gov.bc.ca/2012/sp/pdf/agency/icbc.pdf $>$.

Ibid.

IBC, “Car Insurance,” supra note 22. 
used a flat rate system that does not include gender as a factor. ${ }^{32}$ Manitoba Public Insurance (MPI) is the exclusive provider of basic mandatory auto insurance for drivers in Manitoba, and also determines rates without the use of gender-based risk classifications. ${ }^{33}$

The publicly-provided auto insurance systems in British Columbia, Saskatchewan, and Manitoba do not use gender as a rating variable. ${ }^{34}$ However, even some provinces with private insurance industries have moved to unisex systems. Newfoundland and New Brunswick both have private insurance industries, yet in recent years each of these provinces has prohibited the use of gender as a rating variable. ${ }^{35}$ In both Newfoundland and New Brunswick, discussion surrounding the removal of gender as a rating variable focused mainly on the issue of fairness, rather than constitutional validity. ${ }^{36}$ For those jurisdictions which have moved to unisex auto rating systems thus far, politics and public pressure seem to have been the key motivators behind the switch. ${ }^{37}$

As discussed above, most public insurers in Canada had moved to a unisex system prior to the inception of the Charter in 1982. Consequently, there is no case law in which a public insurer has been challenged under the Charter for using gender as a factor in its auto insurance rating system. However, in provinces that still rate by gender, judicial intervention has yet to result in the discontinuance of the practice. Ontario and Alberta both continue to use gender as a factor in auto insurance rates ${ }^{38}$ and this practice has been upheld as valid under each province's respective human rights legislation. ${ }^{39}$

Ontario was the first to face a challenge in the courts. Insurance legislation in Ontario is unique in that the Ontario Human Rights Code ${ }^{40}$ contains a specific provision which exempts insurers from certain anti-discrimination laws. The Ontario Code states:

Richard Osler, “Sex, Age, Marriage: Insurers Under Attack,” The Financial Post (27 January 1979) 1. See also SGI, "Registration and Insurance Rates," online: SGI <http://www.sgi.sk.ca/individuals/ registration/rates/index.html>.

33 MPI, "Moving Toward a Better Driver Rating System: A Proposal for Improving Manitoba’s Merit Discount and Demerit Surcharge System" (2008) at 2, online: MPI <http://www.mpi.mb.ca/PDFs/DSR DiscussionPaper.pdf $>$.

34 Ibid (for Manitoba); Auto Non-Discrimination Act, supra note 28 (for British Columbia); SGI, supra note 32 (for Saskatchewan).

35 Automobile Rating Classification Regulation, NB Reg 2004-139, s 5(1); Automobile Insurance Prohibited Underwriting Regulations, NLR 80/04, s 4(1)(e.1).

$36 \quad$ Newfoundland, Legislative Assembly, Hansard, 45th Gen, 2nd Sess, Vol 45 No 29 (19 May 2005); New Brunswick Justice and Consumer Affairs, News Release, NB 898, "New Auto Insurance Territories Announced” (7 July 2011), online: Government of New Brunswick <http://www.gnb.ca/cnb/news/jus/ 2007e0898ju.htm>.

37 "Reforms will jack up women's insurance premiums: Blaney,” CBC News (4 July 2007), online: CBC <http://www.cbc.ca/news/canada/new-brunswick/story/2007/07/04/nb-genderinsurance.html>; "Liberals say drivers deserve a better deal, put insurers on notice,” CBC News (19 October 2006), online: CBC <http://www.cbc.ca/news/story/2006/10/19/nb-insuranceplan.html>; "Nfld bans insurance rates based on age, gender," CBC News (13 May 2005), online: CBC <http://www.cbc.ca/news/canada/ story/2005/05/12/ insurance-050512.html>; "B.C. Wants to Remove Age, Sex Basis for Auto Insurance,” The Leader-Post (13 December 1978) 20.

38 Automobile Insurance Rate Board, "Factors That Affect Premium," online: AIRB <http://www.airb. alberta.ca/drivers/factors.aspx>; Financial Services Commission of Ontario, "Understanding Automobile Insurance,” online: Financial Services Commission of Ontario <http://www.fsco.gov.on.ca/en/auto/ brochures/Pages/brochure_autoins.aspx>.

39 Zurich Insurance Co v Ontario (Human Rights Commission), [1992] 2 SCR 321 [Zurich]; Co-operators General Insurance Co v Alberta (Human Rights Commission) (1993), 145 AR 132 (CA) [Co-operators]. RSO 1990, c H-19 [Ontario Code]. 
1. Every person has a right to equal treatment with respect to services, goods and facilities, without discrimination because of race, ancestry, place of origin, colour, ethnic origin, citizenship, creed, sex, sexual orientation, gender identity, gender expression, age, marital status, family status or disability.

3. Every person having legal capacity has a right to contract on equal terms without discrimination because of race, ancestry, place of origin, colour, ethnic origin, citizenship, creed, sex, sexual orientation, gender identity, gender expression, age, marital status, family status or disability.

22. The right under sections 1 and 3 to equal treatment with respect to services and to contract on equal terms, without discrimination because of age, sex, marital status, family status or disability, is not infringed where a contract of automobile, life, accident or sickness or disability insurance or a contract of group insurance between an insurer and an association or person other than an employer, or a life annuity, differentiates or makes a distinction, exclusion or preference on reasonable and bona fide grounds because of age, sex, marital status, family status or disability. ${ }^{41}$

The Zurich case focused on this provision and whether or not gender-based insurance premiums could be justified on "reasonable and bona fide grounds." The Supreme Court found that Zurich Insurance Co. (Zurich) had acted bona fide in setting its insurance premiums, as it had done so in good faith for legitimate business purposes. ${ }^{42}$ However, the main dispute was over whether gender-based premiums were "reasonable."

The Supreme Court set out a two-part test to determine whether the practice was reasonable, asking whether "(a) it is based on a sound and accepted insurance practice; and (b) there is no practical alternative." ${ }^{43}$ The first part of the test was met because Zurich had set rates based on the best interests of its business and had done so according to sound actuarial evidence. ${ }^{44}$ It was held that the second part of the test was also met because no practical alternative to gender-based premiums was said to exist at the time. However, the Supreme Court left the door open by noting that such alternatives may exist in the future, ${ }^{45}$ and that " $[t]$ he insurance industry must strive to avoid setting premiums based on enumerated grounds." ${ }^{46}$ Ontario continues to use gender as a rating variable at this time. ${ }^{47}$

Relying on Zurich, the Alberta Court of Appeal upheld the use of gender-based premiums in the Co-operators case. The Alberta Human Rights Act ${ }^{48}$ prohibits discrimination based on several factors, including gender. Section 11 of the AHRA also contains an exemption; however, it is slightly different than the Ontario Code. The AHRA states:

Ibid, ss 1, 3, 22 [emphasis added].

Zurich, supra note 39 at 348.

Ibid at 342.

Ibid at 348 .

Ibid at 353.

Ibid.

Ontario Code, supra note 40.

RSA 2000, c A-25.5 [AHRA]. 
A contravention of this Act shall be deemed not to have occurred if the person who is alleged to have contravened the Act shows that the alleged contravention was reasonable and justifiable in the circumstances. $^{49}$

The Court of Appeal noted the similarity to the Zurich case in determining whether or not the practice of rating by gender was "reasonable.” The Court stated that the nature of the insurance industry and its need for risk classification means that insurance cases must be given special consideration compared to other human rights cases. ${ }^{50}$ The test from Zurich was used, but with an added requirement of fairness that was imported from the word "justifiable," which appears in the Alberta legislation but not in the Ontario legislation. ${ }^{51}$ The Alberta Court of Appeal found that the Alberta auto insurance industry could remain viable even without the use of gender as a rating variable. ${ }^{52}$ However, it was determined that the removal of gender would result in significant unfairness to young female drivers, and that a genderless system "would not, in [the Court's] view, fairly reflect the disparate risks of different classes of drivers.",53

The Zurich and Co-operators cases are particularly interesting for several reasons. First, they clearly highlight the conflict between the economic fundamentals of the insurance industry and the desire to prevent discrimination in Canadian society. This was referred to by Justice Sopinka in the Zurich case as the "special problem of insurance": 54

The determination of insurance rates and benefits does not fit easily within traditional human rights concepts. The underlying philosophy of human rights legislation is that an individual has a right to be dealt with on his or her own merits and not on the basis of group characteristics. Conversely, insurance rates are set based on statistics relating to the degree of risk associated with a class or group of persons. Although not all persons in the class share the same risk characteristics, no one would suggest that each insured be assessed individually. That would be wholly impractical. Sometimes the class or group classification chosen will coincide with a prohibited ground of discrimination, bringing the rating scheme into conflict with human rights legislation. ${ }^{55}$

Second, the findings in these cases rely heavily on an uncertainty about whether there are effective alternatives to gender-based rating systems. In Zurich, for example, one of the main reasons behind the ruling was that there was no practical alternative to gender-based rating. ${ }^{56}$ Alternatively, in Co-operators it was determined that gender was not a necessary rating factor. ${ }^{57}$ Given that many jurisdictions have moved to unisex systems and have been able to maintain viable insurance industries — particularly recent moves by jurisdictions with private auto insurance — these concerns might carry less weight today.

Ibid, s 11 [emphasis added].

Co-operators, supra note 39 at paras 51-52.

Ibid at para 54.

Ibid at para 80 .

Ibid at para 88.

Supra note 39 at 24 .

Ibid at 23-24.

Ibid at 39.

Supra note 39 at 318. 
Finally, on a related note, the cases on point are decades old. It is yet to be seen whether challenges to gender-based rating systems would have the same outcome today. There has been a recent trend toward unisex systems, such as in New Brunswick and Newfoundland, as well as in the Association belge des Consommateurs Test-Achats ASBL v. Conseil des Ministres $^{58}$ case from the ECJ, discussed in the next Part. Given these factors, there may be increased societal pressure on courts to invalidate gender-based rating systems. Even the Supreme Court of Canada in Zurich emphasized that insurers must, where possible, avoid using rating variables that conflict with the equality values protected by human rights legislation. ${ }^{59}$

\section{INSURANCE IN OTHER COUNTRIES}

In discussing the use of gender in auto insurance rates, it is helpful to look at how some other jurisdictions have dealt with the issue. What trends are emerging in the field of human rights as it relates to auto insurance rates globally? What have been the effects in regions where gender has been removed as a rating variable? A comprehensive review of the global situation is beyond the scope of this article; however, a few examples from the United States and Europe are instructive.

In the state of Pennsylvania, there has been significant legal discussion regarding how auto insurance rates interact with human rights legislation. In the 1984 case of Hartford Accident and Indemnity Co. v. Insurance Commissioner of the Commonwealth of Pennsylvania, ${ }^{60}$ the Supreme Court of Pennsylvania upheld a decision by the state's Insurance Commissioner to prevent insurers from using gender as a rating criterion. The decision provides an excellent example of the conflict between the economics of insurance and the desire to enforce broad human rights legislation and public policy.

Pennsylvania's Rate Act ${ }^{61}$ stated that insurance rates "shall not be excessive, inadequate or unfairly discriminatory." 62 The main dispute was over the interpretation of the phrase "unfairly discriminatory." Insurers argued that the fairness of a risk factor should be based solely on whether or not the rating factor could be supported by actuarial data. However, the Commissioner held that the phrase "unfairly discriminatory" must be interpreted in a manner consistent with Pennsylvania's Equal Rights Amendment, ${ }^{63}$ in which "[e]quality of rights under the law shall not be denied or abridged in the Commonwealth of Pennsylvania because of the sex of the individual." ${ }^{4}$ The Court held that fairness was "a legislative concern distinct from and transcending the need for sound actuarial justification.” ${ }^{65}$ Furthermore, the Court held that excluding sex discrimination from an interpretation of "unfairly discriminatory" would contradict the Equal Rights Amendment, and therefore, sex discrimination must be interpreted as unfair. ${ }^{66}$

OJ c 205, online <curia.europa.eu> [Test-Achats].

Supra note 39 at 353.

482 A (2d) 542 (Pa Sup Ct 1984) [Hartford].

40 PS (1971).

Ibid at 545, citing Rate Act, ibid, § 1183.

PA Const art 1.

Hartford, supra note 60 at 547, citing Equal Rights Amendment, ibid § 28.

Hartford, Ibid.

Ibid. 
The case of Pennsylvania National Organization for Women v. Commonwealth of Pennsylvania Insurance Department ${ }^{67}$ addressed the issue of whether unisex auto insurance rating may itself be discriminatory because it raises rates for women. The National Organization for Women (NOW) argued that by using unisex rates, women were unfairly subsidizing a reduction in auto insurance rates for men. In particular, NOW argued that the Insurance Commissioner should force insurers to take into consideration the fact that women have a significantly lower annual mileage than men. Through the Commissioner's failure to do so, NOW claimed that women were bearing more than their fair share of the accident risk distribution. ${ }^{68}$ The Court held that the unisex rating scheme was valid. Following the Hartford decision, the Court stated that there could be no legal burdens or benefits imposed merely because of an individual's gender. ${ }^{69}$

The most recent judicial consideration of gender in auto insurance rates comes from the ECJ in the case of Test-Achats. In 2003, the European Commission had adopted an equal treatment directive aimed at eliminating sex-based discrimination in access to and supply of goods and services. ${ }^{70}$ One article within this directive granted an exception under which member states could decide to continue using gender as a rating factor as long as it was based on "relevant and accurate actuarial and statistical data."71 The Test-Achats case was focused on determining the validity of this exception. The ECJ held as follows:

Such a provision, which enables the Member States in question to maintain without temporal limitation an exemption from the rule of unisex premiums and benefits, works against the achievement of the objective of equal treatment between men and women, which is the purpose of Directive 2004/113, and is incompatible with Articles 21 and 23 of the Charter. ${ }^{72}$

The exception was deemed to be invalid, effectively banning the use of gender as a rating variable across the European Union. The decision took effect on 21 December 2012 and the effects of the decision, both social and economic, will be pertinent to potential future considerations of this issue in the Canadian legal system.

\section{Analysis}

So, what conclusions can be drawn about whether the use of gender as a rating variable is legally justifiable in Canada? As the discussion above illustrates, the issue of gender-based auto insurance rating systems touches on a much broader conflict: the relationship between the fundamental economics of insurance and the progression of modern social policy. The need for insurers to distinguish between risks and the evolution of modern equality laws are fundamentally in conflict with regards to the use of gender as a rating variable. The question is how to reconcile this conflict.

551 A (2d) 1162 (Pa Commw Ct 1988) [Pennsylvania National].

Ibid at 1167 .

Ibid.

Test-Achats, supra note 58 at para 4; Andres Webersinke, "The European Battle Over Sex: Human Beings are Above Statistics” (2012) 55 International News 35 at 35.

Test-Achats, ibid at para 6.

Ibid at para 32 . 
The Charter is a powerful tool in the fight against discrimination. In particular, section 15 expressly prohibits the use of sex as a means of distinguishing between individuals. Although all public auto insurers in Canada have discontinued sex-based rating systems, it is still relevant to discuss the potential application of the Charter. There are often crucial similarities between the Charter and provincial human rights legislation, and provincial human rights statutes are themselves subject to the Charter. ${ }^{73}$ The test set out in Kapp is instructive regarding how courts understand discrimination. It would likely inform determinations of whether using gender to set auto insurance premiums constitutes discrimination or is merely a legitimate form of distinction.

The test in Kapp states that, in determining whether an activity is discriminatory, courts must ask whether this activity creates a distinction based on an enumerated or analogous ground, and whether this causes a disadvantage by perpetuating prejudice or stereotyping. ${ }^{74}$ Clearly, gender-rating auto insurance systems intentionally distinguish based on the enumerated ground of sex, so the main issue is with the second part of the test. Do genderbased rating systems cause a disadvantage by perpetuating prejudice or stereotyping?

Kapp begins by noting the relationship between sections 15(1) and 15(2) of the Charter. Section 15(2) essentially provides an exclusion from 15(1), allowing for a law, program, or activity to discriminate if its purpose is "the amelioration of conditions of disadvantaged individuals or groups.” Kapp states that, if a government can justify a program under section 15(2), there is no need for a section 15(1) analysis. ${ }^{75}$ However, in this discussion the use of gender as a rating variable has no ameliorative purpose. It is merely intended to improve the accuracy of underwriting practices. In fact, this is not even an active program per se, but rather a permissive legal regime which allows for the practice by private companies. As such, a section 15(1) analysis is needed.

In determining whether a law or practice is discriminatory, Kapp looks at two main factors: perpetuation of disadvantage and stereotyping. ${ }^{76}$ Regarding perpetuation of disadvantage, the analysis considers pre-existing disadvantages of the claimant group and the nature of the interest affected. It is difficult to argue that young males are a group with a history of pre-existing disadvantage. It may be suggested that they have experienced disadvantage within the context of automobile insurance premiums; however, this leads to a discussion of the nature of the interest affected.

The right to pay lower insurance premiums is not of great significance. As explained in the case of Law v. Canada (Minister of Employment and Immigration), an analysis of the nature of the affected interest must consider

Peter Hogg, Constitutional Law of Canada: 2010 Student Edition (Toronto: Carswell, 2010) at 55-12. See Kapp, supra note 27 and the related text.

Ibid at para 37.

Ibid at para 23. 
not only the economic but also the constitutional and societal significance attributed to the interest or interests adversely affected by the legislation in question. Moreover, it is relevant to consider whether the distinction restricts access to a fundamental social institution, or affects "a basic aspect of full membership in Canadian society”, or “constitute[s] a complete non-recognition of a particular group”. 77

It is difficult to argue that an interest in slightly cheaper automobile insurance concerns a fundamental social institution, or affects a basic aspect of full membership in Canadian society. It is unlikely that the small difference in price constitutes even a minor impediment to the operation of a motor vehicle for most drivers. There is an economic interest at stake; however, the "constitutional and societal significance" of this premium differential is not of great importance overall.

Regarding stereotyping, Kapp considers the degree of correspondence between the differential treatment and the claimant group's reality. There is, in fact, a great deal of correspondence between the treatment of men and women in determining their automobile insurance premiums and the actual risk of loss each group poses. Essentially, charging young males a higher rate reflects the reality that they are statistically riskier drivers than their female counterparts. ${ }^{78}$

Overall, it would seem that under the Kapp analysis the use of gender as a rating variable in automobile insurance would not likely be considered discriminatory. However, one key point is that this conclusion is based on the fact that current statistics tend to show that women are safer drivers than men, particularly among younger drivers. If this were to change and the statistical gulf in loss ratios between young men and women was to become smaller, it is possible that this practice would no longer be justifiable under Kapp.

As discussed above, the higher risk of loss among young males is not caused by gender; rather, gender is a proxy for other causal factors, such as annual mileage. ${ }^{79}$ As gender roles change and young women drive more, it is possible that this gap in loss ratios may decrease. There is also a strong possibility that if this difference in loss ratios between men and women were to disappear, insurers may simply adjust rates independently in order to reflect this shift in actuarial data. This would likely vitiate the need for government or judicial intervention into underwriting practices.

I now turn to two of the major arguments raised to support the continued use of gender as a rating variable in auto insurance. The first argument is based on commercial efficacy and essentially holds that, without using gender, it would be difficult or impossible to effectively classify risks and maintain a viable automobile insurance industry. ${ }^{80}$ The second argument is about fairness, and suggests that it is unfair for young women, who are relatively low-risk applicants, to pay higher premiums to subsidize their high-risk male counterparts. ${ }^{81}$ Both arguments were addressed in the Co-operators and Zurich cases mentioned above; however,

[1999] 1 SCR 497 at para 74 [Law], citing Egan v Canada, [1995] 2 SCR 513 at para 64. Supra note 16.

See supra note 19.

Faure, supra note 5 at 93; Schmeiser, Störmer \& Wagner, supra note 8 at 15; Co-operators, supra note 39 at para 62.

81 Faure, ibid at 94; Schmeiser, Störmer \& Wagner, ibid at 15; John D Hatch, "Should Insurance Be Blind to Sex?” (1983) 12 Brief 9 at 10; Co-operators, ibid at para 107. 
recent developments in Canadian case law, coupled with the shift to unisex systems in provinces like New Brunswick and Newfoundland, bring new perspective to this discussion.

The commercial efficacy argument is often used to suggest that the switch to a unisex system would result in major economic upheavals in the insurance industry. As mentioned earlier, it is crucial for insurers to be able to classify risks in order to avoid the issues of moral hazard and adverse selection. ${ }^{82}$ It is sometimes suggested that without gender as a rating variable, insurers will not be able to create accurate rating systems, resulting in the destabilization of the industry overall. ${ }^{83}$ Insurance providers in provinces such as British Columbia, Saskatchewan, and Manitoba have been operating without the use of gender for decades; however, these are examples of publicly-run insurance industries with government monopolies. In the past, it may have been suggested that the same success would not follow in privatized systems, but the experience in provinces like Newfoundland and New Brunswick may disprove this argument if they are successful in the long term. ${ }^{84}$

One suggestion to ensure commercial viability is to replace gender with another variable. Gender is not causally related to probability of loss; it is merely a proxy for other factors, such as higher overall mileage. ${ }^{85}$ For example, it may be better to use mileage as a variable directly rather than using gender. This suggestion has been rejected in the past because monitoring mileage has historically been viewed as highly cost-prohibitive. ${ }^{86}$ However, given modern advancements such as the increasing use of GPS systems in vehicles and the everaccelerating progression in computer technology, it is likely that monitoring costs may not be as unreasonable as they once were. In the Co-operators case, the Alberta Court of Appeal made it known that it would be unfair to remove gender as a rating factor without replacing it with another variable. ${ }^{87}$ Using mileage was said to be impractical at that time, but this may no longer be true.

Some have even suggested that risk classification is not a fundamental economic necessity in the insurance industry, but rather a competitive tool that can be used by individual insurers to create a more effective rating system. ${ }^{88}$ If this is the case, it may actually be beneficial for individual insurers to implement a mileage-based system if it can be done in a manner that is both cost-effective and allows for more accurate risk classification. An insurer who is able to accomplish this may be able to set rates in a manner that would attract desirable clients, help to create a stable risk pool, and potentially increase profitability.

Regarding the problem of fairness, the main concern is that removing gender as a rating variable will lead to drastic rate increases for young women. In essence, forcing both men and women to pay the same rates will cause a subsidization of bad risks by good risks. ${ }^{89}$ Young women would essentially be forced to pay for the rate reduction for their more risky

See supra note 5.

Supra note 80.

IBC, Facts, supra note 3.

See supra note 19.

Wiegers, supra note 1 at 182-83.

Co-operators, supra note 39 at 320.

Baker, supra note 4 at 377-78.

Faure, supra note 5 at 94. 
male counterparts. ${ }^{90}$ In the Co-operators case, the ruling of the Alberta Court of Appeal hinged on the fact that removing gender would be extremely unfair for young women due to these expected rate increases. ${ }^{91}$ Arguably, such a move would result in a decrease in premiums for young men, but this decrease would not likely match the increase to young women. ${ }^{92}$

Further, due to the loss of this rating factor, many insurers might need to compensate for the loss of accuracy in risk assessment by increasing premiums overall. ${ }^{93}$ However, premium increases may not be as drastic as expected. ${ }^{94}$ In Michigan, for example, where unisex rating was implemented in 1981, average rate increases were only 20.9 percent for young women and likely much less than that when taking into account the lower ticket and accident rates of young women. ${ }^{95}$ This may be especially true in private markets where individual insurers are competing for clients. Large rate increases by one insurer may simply lead clients to move to a different insurer with a less severe increase. In addition, this inter-company competition may result in the implementation of other factors, such as mileage, as discussed above, so that insurers create more accurate risk assessment and become more competitive in the marketplace. Historically, public markets have been first to effectively introduce genderless rating systems; however, private markets may ultimately be the best place to see this accomplished.

Another counterpoint to the fairness concern is that, although it may seem unfair to young women with lower annual mileage to be forced to pay more for their insurance, it is equally unfair for young men who have low annual mileage to be lumped together with other, riskier males. One of the main philosophical underpinnings of anti-discrimination laws is that it is repugnant that people be judged based on presumptions which are associated with innate characteristics over which they have no control. ${ }^{96}$ In the insurance context, this means that factors such as ethnic origin, race, and gender should not be used to distinguish between applicants. Even if there is a correlative relationship between gender and average risk of loss, it seems unfair to judge the risk of an individual applicant based on the presence or absence of a Y chromosome. As stated by Justice L’Heureux-Dubé , dissenting in the Zurich case,

[d]iscrimination based on statistical correlation is simply discrimination in a more invidious form.

This is not to say that statistics could not be used to justify the discriminatory rate classification system. On the contrary, strong statistical proof is required to demonstrate a rational connection between the discriminatory classification and high risk. This proof, however, must not simply be one of correlation, but one of causal connection. ${ }^{97}$

See supra note 74 .

Supra note 39 at 320.

Hatch, supra note 81 at 10.

Ibid.

Frances K Wallace, “Unisex Automobile Rating: The Michigan Experience” (1984) 3:2 Journal of Insurance Regulation 127 at 134.

Ibid at 129.

Jerry \& Mansfield, supra note 1 at 367.

Supra note 39 at 371 [emphasis in original]. 
On the other hand, factors such as the number of convictions, accident history, and annual mileage are within the control of an applicant and, therefore, can be fairly used to assess the risk of potential loss.

An added component of the fairness issue is that the roles of men and women are continually shifting over time. While, at one point, men may have driven more often than women, this is not necessarily the case today. An understanding of the modern evolution of gender roles means that we should no longer assume that men or women will act in a certain way simply because of their gender. Archaic stereotypes should no longer be given the recognition they once were, and perpetuation of those perspectives will only inhibit what should be their eventual extinction.

Another consideration that arises relates to the definition of fairness itself. Insurers often argue from a point of view of "actuarial fairness"; in other words, they view the fairness of a rating variable as determined by whether or not it is based on statistics that can show a relevant distinction between risks. ${ }^{98}$ This analysis was rejected in the Hartford case. ${ }^{99}$ It was held that the notion of fairness transcended mere actuarial fairness, and constituted an end that was much broader. Although one may argue that the unique nature of insurance warrants a unique understanding of fairness, the interpretation in Hartford is the correct one. Actuarial fairness is not the same thing as fairness in general. Certain factors, over which an insured may have no control, may be used to determine premiums under the guise of actuarial fairness. As stated by Tom Baker, "[a]ctuarial fairness saddles people with all the consequences of their high risk status, whether deserved or not. Conversely, it entitles other people to all the benefits of their low risk status, also whether deserved or not." ${ }^{100}$ For example, even if it could be proven that people of a certain race or religion were statistically more likely to be involved in an automobile accident, it is highly unlikely that society would approve of the use of such variables in setting premiums. Here we can see that there is a much broader sense of fairness in Canadian and other legal systems that is fundamental to the understanding of equality.

\section{Conclusion}

The practice of risk differentiation by insurers easily comes into conflict with principles of equality when the issue of gender is considered. Insurance is a very important industry with very unique characteristics, and it is sometimes difficult to apply human rights legislation to insurance cases in the same manner as they are applied to other legal issues. However, this does not make insurers immune from equality laws and does not grant a blanket exception to use any statistically relevant factor in setting rates.

Is the use of gender in auto insurance rating systems legally justifiable? Canadian law seeks to promote equality and to prevent discrimination against individuals based on certain characteristics, one of which is gender. However, as discussed in Part V, the use of gender

Deborah S Hellman, “Is Actuarially Fair Insurance Pricing Actually Fair?: A Case Study in Insuring Battered Women” (1997) 32:2 Harv CR-CLL Rev 355 at 358; Baker, supra note 4 at 392; Hartford, supra note 60 at 547; Co-operators, supra note 39 at para 92. 
alone may not necessarily constitute "discrimination" as understood in the context of Canadian law. Insurance providers do not arbitrarily distinguish based on the physical characteristic of gender; rather, they use gender as one of many factors to establish an individual's probability of loss. In the case of automobile insurance, it is difficult to argue that the effect of this practice is detrimental to a disadvantaged group or that it impacts a fundamental social or constitutional interest. Crucially, the distinction drawn is based on actuarial statistics which reflect a real difference between men and women. Under the current understanding of discrimination, is it likely that gender-based rating systems are legally justified.

However, this is not the end of the discussion. There are still broader public policy considerations involved, which may impact whether insurers will be allowed to continue using gender as a rating variable. As noted earlier, in many of the jurisdictions where unisex rating systems were adopted, it was social and political motives which prompted the change. ${ }^{101}$ Even if it is legally justifiable, the greater question will be: Do the benefits of promoting equality in the broader context of Canadian society and the Canadian legal system outweigh the potential costs of prohibiting the use of this rating variable in auto insurance? For factors like race and religion, the answer has been yes. Given the absence of discussion surrounding this issue in recent years, the answer for gender is still uncertain.

It is generally understood by both insurers and insureds that premiums must be based on statistical probability of loss. However, in the case of gender-rating, how this probability is calculated speaks to what Canadians and those in greater Western society consider to be acceptable ways of distinguishing between individuals. Though it may be legally justifiable, it is not necessarily socially justifiable. There must be a strong and widespread effort to promote equality wherever possible and the insurance industry, even despite its distinct economic characteristics, should not be excused from this effort. The unique nature of the insurance industry will simply mean that insurers must find unique solutions to differentiate risks without the use of gender as a variable. 